\title{
John Stuart Mill's Philosophy of Persuasion
}

\author{
HELEN MCCABE
}

Politics and International Studies

University of Warwick,

Coventry CV4 7AL,

$U K$

H.R.McCabe@warwick.ac.uk

\begin{abstract}
In his youth, John Stuart Mill followed his father's philosophy of persuasion but, in 1830, Mill adopted a new philosophy of persuasion, trying to lead people incrementally towards the truth from their original stand-points rather than engage them antagonistically. Understanding this change helps us understand apparent contradictions in Mill's canon, as he disguises some of his more radical ideas in order to bring his audience to re-assess and authentically change their opinions. It also suggests a way of reassessing the relationship between Mill's public and private works, to which we should look if we are attempting to understand his thought.
\end{abstract}

Résumé: Dans sa jeunesse, John Stuart Mill a suivi la philosophie de la persuasion de son père, mais en 1830 Mill a adopté une nouvelle philosophie de la persuasion en essayant d'amener les gens progressivement vers la vérité à partir de leur perspective plutôt que communiquer de manière antagoniste. Comprendre ce changement nous aide à comprendre les contradictions apparentes dans l'œuvre de Mill, car il déguise certaines de ses idées les plus radicales pour amener son auditoire à réévaluer et changer authentiquement leurs opinions. Comprendre ce changement suggère aussi une façon de réévaluer la relation entre les travaux publics et privés de Mill, que nous devons examiner si nous essayons de comprendre sa pensée.

Keywords: John Stuart Mill, James Mill, philosophy of history, persuasion, associationist psychology.

\section{Introduction}

Throughout his life John Stuart Mill wrote primarily for a public audience, with the intent of affecting political outcomes through mobilising public opinion either to bring weight to bear on elected politicians, or to change social mores. ${ }^{1}$ Mill's writings are then, in the main, persuasive texts. It is generally recognised amongst modern readers and scholars that Mill was not writing analytical philosophy in the ways of today's political philosophers, but I do not think we have quite understood what Mill's

\footnotetext{
${ }^{1}$ This article is substantially based on a paper delivered at the ISUS X conference at Berkeley in 2008. My thanks to the AHRC for helping fund my attendance and research.
} 
persuasive project was, and thus run the risk of reading him wrong. $^{2}$ In this article I wish to offer a way of understanding Mill's philosophy of persuasion (and how that changed during his lifetime) in order that we may gain a greater understanding not only of what he wrote, but also why he wrote it in that way.

In his youth, Mill's philosophy of persuasion was, like the political theory of which it formed a part, aligned with his father's. This persuasive philosophy had two prongs: repeating rational arguments until people were forced to see their truth, and thus assent to them, and educating people so that they associated the right things with pleasure, and the wrong things with pain (Mill 1981, 109; Hamburger 1963, 25; James Mill 1825, 12-14). However, one of the outcomes of Mill's famous 'crisis' in 1826/7 was his adoption of an almost entirely different philosophy of persuasion, based on trying to bring people, from their own standpoints, to change their views incrementally until they had better opinions, which they had formed for themselves. In order to help people make these incremental changes, Mill changed his philosophy of persuasion from challenging his readers directly with rational arguments, to revealing his own opinions in an equally incremental manner, depending on how he judged public opinion at the time, and what changes he could justifiably expect to bring about. The realisation that this is how Mill chose to argue, coupled with the fact that almost all of his texts are aimed at persuading his readers, means that we need to bear in mind whom Mill considered to be his audience, what change he might have been trying to bring about, and the context within which he was arguing (which reveals how radical he felt he could afford to be) whenever we read any of Mill's works: the immediate content of his writing after 1826/7 does not reveal everything about his political theory.

In this article I wish to put forward this argument in the following manner. Firstly, by assessing James Mill's philosophy of persuasion as Mill understood it, and as Mill engaged in it when he first began writing persuasive pieces (in the 1820s),

\footnotetext{
${ }^{2}$ Good work has been done on explaining what rhetorical devices Mill employed in particular texts, for instance Margaret Canovan's analysis of Mill's creation of a particular authorial voice in On Liberty. It is the different, further question of why he did this-his philosophy of persuasion, not the particular methods he utilised in particular texts - with which I am interested here (Canovan, 505-15). Similarly, Frederick Rosen's discussion of Mill's use of dichotomy to show both sides of a question is related to my understanding of Mill's philosophy of persuasion, though Rosen does not explain why Mill had such a philosophy (or 'method of reform'), nor exactly what it was (Rosen, 69 and 231-2).
} 
secondly, by examining how Mill's attitude to this philosophy of persuasion changed after his famed mental 'crisis' of 1826/7, thirdly, by identifying how Mill's philosophy of persuasion changed in the light of his crisis, and lastly illustrating this with a brief examination of the light it sheds on some apparent contradictions in Mill's feminism.

\section{Mill's philosophy of persuasion in the early $1820 \mathrm{~s}$}

In his Autobiography, Mill categorises the 1820s as the period of his 'most extreme Benthamism' (Mill 1981a, 137). The philosophy of persuasion in which Mill was engaged as a part of championing Benthamite radicalism was an important part of his political thought at the time. Both were based (in part) on his father's political thought, and on 'associationist psychology', a school of philosophy of mind based on the work of David Hartley, which James Mill extended or re-founded with his Analysis of the Phenomena of the Human Mind (Mill 1981a, 107-9 and 590; Mill 1989, 99; Hamburger 1963, 25; Hugeulet 1966, xii).

Associationist psychology had a great deal of bearing on the philosophy of persuasion adopted by James Mill in the early 1800s (Mill 1981a, 109; Hamburger 1963, 25). One aspect of this - and the aspect most shared by John Stuart Mill at that time - was to repeat rational arguments over and over again until people were forced to both rationally, and practically, assent to them (Mill 1981a, 590 and 109; Mill 1989, 99; Hamburger 1963, 25; Hugeulet 1966, xii).

To explain the basis of this philosophy of persuasion, we must look a little closer at associationist psychology. James Mill and Hartley held that all our ideas, sensations and 'internal Feelings' (such as, importantly, conscience), come from outside our bodies, and are all attended by either pleasure or pain (Hartley, ii; Mill 1981, 590; Hugeulet, xii; James Mill 1869, esp. 52 and 70-126). As all our ideas about morality come from external stimuli, then it must be the different institutions under which men live, which give them their ideas of morality. Hence, if we change institutions, we can change men. Similarly, one way of 'persuading' people to do something is to train them to associate doing it with pleasure (and not doing it, or doing something bad, with pain). (Additionally, for James Mill, as this theory of psychology shows that the only internal thing which unites all humanity is the seeking of pleasure and the aversion to pain, Utilitarianism becomes the only rational and justifiable foundation for all human institutions.) 
In order to change institutions (and thus change men), one has to get those people who can change the law to agree to changes, and this is where the second prong of James Mill's philosophy of persuasion comes in. Hartley argued that once we see the truth of propositions, we cannot but rationally assent to them (Hartley, 324). Repeated rational assent to something forces us to also give it our practical assent (Hartley, 324-5). This is important as it is this form of assent that makes us ready to act upon the beliefs we have assented to-rational assent is not enough in itself (ibid.). The more we are confronted with a truth, to which we must rationally assent, the more we are forced also to assent practically, and thus to act upon it (ibid.).

Like Hartley, James Mill believed that association was made stronger by repetition (James Mill 1869, 87). Although he accepted that some people carried on associating ideas (such as ghosts with the dark) even when they did not really believe in the truth of the idea anymore, James Mill also thought that new associations, leading to the recognition of new truths, could bring about new beliefs (James Mill 1869, 87). ${ }^{3}$

It is for this reason that, as Mill records, his father had 'almost unbounded confidence' in 'complete freedom of discussion' (Mill 1981a, 109): free and public discussion brings new truths to people's attention, which they have no choice but to accept, and, eventually, such free discussion will also change their behaviour and make them act on those propositions (and will, eventually, if united with representative government elected by universal suffrage be the best means of ensuring good government) (ibid).

In brief, James Mill's philosophy of persuasion had two strands. Firstly, he believed that one could train people, through the association of pleasure and pain, to seek certain things and avoid others. For example, he felt that the pain of public disapprobation could prevent people from having too many children, as could the pleasure of public approbation at their self-control (James Mill 1826, 58-9). Secondly, he believed that repeated rational argument could force people to accept the truth of a statement.

James Mill's practical action on this aspect of persuasion is to be seen in his belief that newspapers had to highlight the ills of government, and keep repeating them (Hamburger 1963, 25). It seems plausible that John Stuart Mill adopted this same

\footnotetext{
${ }^{3}$ Interestingly, James Mill may have had Jeremy Bentham in mind when he talked about men who feared ghosts though they did not believe in them (Schofield, 1).
} 
attitude towards bringing about reform just as he adopted almost all of his father's political, social, economic and philosophical thought at this period. Certainly, Mill wrote a number of articles on much the same topic during the 1820 s, for example, nine on religious tolerance and libel laws in the space of two years, and his belief in the power of repeating rationally-acceptable truths would be a credible explanation of this (Mill 1986, 6, 9-15, 215, 30-34, 42, 46-8, and 91-5).

In sum, then, I contend that in the 1820 s, when Mill first began to write texts which were aimed at persuading public opinion, his persuasive philosophy was aligned with his father's, and, in particular, being based on the principles of associationist psychology, was concerned with one particular aspect of his father's method, that of confronting the public with rational arguments, and repeating them until people had to acknowledge the truth of them, and were forced to give their assent. I also contend that this philosophy of persuasion changed dramatically during the years following Mill's crisis of 1826/7, as he rejected both aspects of his father's philosophy of persuasion, as the following section will endeavour to show.

\section{Mill's philosophy of persuasion after his mental 'crisis'}

In the winter of $1826 / 7$, Mill suffered what he refers to in his Autobiography as a 'crisis in [his] mental history' in which his faith in the Benthamite project of reform crumbled (Mill 1981a, 137-45). I believe a part of Mill's rejection of his previous Benthamism was a rejection of his old way of trying to change public opinion, and his adoption of a different philosophy of persuasion.

Mill's rejection is closely connected to an increasing concern with the 'naturalness' or authenticity of ideas - that is, Mill's desire that feelings and opinions be born of something inside a person, and not moulded onto them by some outside force, an aspect of his crisis to which I will turn in more detail below. This led to the following six reasons for doubting the efficacy of his father's philosophy of persuasion. Firstly, Mill doubted that people could be brought to change the world through educating them to associate 'virtue', or the right ideas, with pleasure, and 'vice', or the wrong ideas, with pain because these resulting associations would be artificial (Mill 1981a, 141). Secondly, he came to believe that the associations supporting these artificial feelings were prone to being destroyed by our powers of analysis (ibid.). Thirdly, he believed that only authen- 
tic (inartificial) opinions, which were attached to and supported by real, authentic, feelings, could command our practical assent, and hence action (ibid.). These three reasons are all primarily associated with his father's belief that one way of persuading people to accept or reject an idea was to train them to associate pleasure or pain with it. Fourthly, Mill realised that debate only made people cling more strongly to their erroneous beliefs. Fifthly, he determined that no one's opinions were wholly correct, or wholly wrong. Sixthly, he came to believe that critical debate was one of the symptoms of the deeper problems of his time, problems that could partly be cured by a movement away from this kind of critical thinking. These latter three reasons are all primarily connected with his father's method of persuading people through repeated restatement of one's rational beliefs, which Mill had himself also engaged in. In order to better understand how and why Mill rejected his father's philosophy of persuasion, in which he himself had engaged in the 1820 s, I will next examine each of these six points more closely.

To begin, then, my first point is that Mill determined that opinions founded on associations of pleasure and pain were artificial and inauthentic. The belief that people could be brought to associate the 'right' things with pleasure and the 'wrong' with pain was the basis of James Mill's educational system (James Mill 1825, 12-14). This need not be as simple or direct as causing someone pain when they do something bad-for example, Mill's knowledge of Greek and Latin, and admiration for Greeks and Romans, was used to foster support for democracy in modern times - though this seems to have formed part of it (Mill 1981a, 23; Mill 1981c, 612-13). This educational and persuasive method may also be the root of why Mill recalls his conscience always spoke to him in his father's voice, for it was his father's early training in associating certain actions with 'good' and 'bad' that gave him his earliest moral code (Mill 1981c, 613).

In 1826/7 Mill declared that his father's system of education, even when it worked, led only to 'artificial' associations (Mill 1981a, 141). We can be forced, especially through pain, to aver something, but that aversion is only grounded in our aversion to pain, and not in any real understanding of why we should avoid the actual action itself (ibid.). Mill determined that what he called the 'old ... instruments' of 'praise and blame, reward and punishment' (his father's preferred methods) resulted in ideas being associated with either pleasure or pain artificially, and not through any 'natural tie' (ibid.). People may well be malleable, and the institutions his father wished to see created might well have formed people's characters in such a way as 
they associated virtuous things with pleasure, and vicious things with pain, but this meant that people would only do a virtuous thing for the pleasurable reward, or refrain from doing a vicious thing because they feared the resulting pain, and not because they felt they should be virtuous and not vicious.

I suggest we call this problem Mill's concern for naturalness, or authenticity - for feelings to be born of something inside a person, and not moulded onto them by some outside force. Naturalness, inartificiality, self-creation and authenticity were certainly things with which Mill was much concerned at this period, being very distressed by the idea that he was a man 'manufactured' or 'made' by his father and incapable of having his own, self-generated, authentic, opinions (Mill 1981d, 132). Indeed, in 1833 he wrote that it was far more important that people had authentic feelings and opinions than that these opinions were true or right (Mill 1981e, 369). Mill seems to have believed that what was important were opinions which were born of a man's very nature, and gave us knowledge of his individual character at the deepest level (ibid.). He was also highly concerned that things really were felt by people, from deep within, even going so far as to say that knowing that other people really feel, and having sympathy for their ability to feel, is what makes the difference between living life, and getting through it, not least because the knowledge that there has been nobleness and great feeling in the world inspires us to the struggle to achieve them ourselves (Mill 1981e, 369-70). Again, the emphasis is on real feelings, coming from an individual's own soul - from the very depth of their being - and on individual experience. Simply because authenticity is of paramount importance, then, Mill rejected his father's attempts to train people to associate pain and pleasure with the 'right' opinions, because this approach did not create authentic opinions.

The problem of authenticity also led to Mill's rejection of his father's philosophy of persuasion for a second reason; such opinions were prone to destruction by our own powers of analysis. Mill believed, as already mentioned, that his father's methods only engendered artificial associations. Mill also believed (from his own experience) that these artificial associations were prone to being broken down by our powers of analysis (Mill 1981a, 141). This is because analysis, which is a natural part of anyone's mental make-up, but is also encouraged and strengthened by rational argument, enables us to separate ideas, however long we have been trained to consider them as indistinguishable (ibid.). Hence, although Mill still believed that analysis can help us see the real connections between cause and effect, or between 
things joined by natural laws, he realised that the habit of analysis would destroy all virtue founded solely on associations of feeling (Mill 1981a, 141-3). Mill concluded that he had no real desire to see the reforms for which he had once been a standardbearer achieved, for he could feel no authentic connection between that achievement and his own happiness (Mill 1981a, 143). As Mill puts it '[ $\mathrm{t}]$ he end had ceased to charm ... how could there ever again be any interest in the means?' (ibid). His commitment to these reforms had been based entirely on associating them with pleasure, and not in any authentic belief in them-once that association was broken, so, in the darkest period of his 'crisis', was all belief in the reforms themselves. Moreover, although Mill regained his commitment to many radical reforms, and campaigned for them for the rest of his life, this commitment was not founded on his attachment of the personal experience of pleasure to their achievement, as he had done in the 1820s. Mill's crisis made him realise that his father's philosophy of persuasion, therefore, although it might work in the short-term, in the long-term led to disillusionment and despair. Worse, it was one aspect of his father's method - that of repeating rational arguments-which would, by strengthening our reason and powers of analysis, undermine the education brought about by the other aspect, that of training people to associate good things with pleasure, and bad things with pain. His father's philosophy of persuasion was, then, ultimately selfdefeating.

This leads me to Mill's third problem with his father's philosophy of persuasion, that only those opinions which are authentically ours can command our action. This is the corollary of what Mill discovered in himself in his 'mental crisis'; the ends ceased the charm, and thus so did acting to achieve the means. If we are attached to the ends only through training, therefore, when our analysis attacks this attachment and destroys it, we will no longer pursue either it, or the means to it. But when the end had 'charmed', Mill had been an active and vociferous pursuer of the means. Hence, I contend, he determined that if we could have a natural, authentic attachment to the end, we would pursue the means. If one wants to persuade people to pursue institutional change, therefore, one must elicit an authentic emotional attachment to the reforms one proposes in order to get people to act upon them.

As I noted above, Mill had been concerned that people avoiding a certain course of action due to their associating either pleasure or pain with it, was both unsustainable (as their powers of analysis would break these bonds of association and destroy 
the original motivating force which led them to action), and wrong (as it lead to artificial, or inauthentic, opinions, and not natural, authentic ones). This new idea, although based in utilitarianism, and hence on seeking pleasure and avoiding pain, is not doing the same thing. Mill had a problem with people avoiding a certain action because they had been trained to expect a painful response when they followed it, or following a course of action because they had been trained to expect a pleasurable response from it, rather as one trains animals. However, he still believed that we do indeed follow certain courses of action because they result in pleasure, and desist from following others because they result in pain, but Mill wanted that feeling of either pleasure of pain to be more intrinsically attached to the action that his father's educational plans. So, for example, one can imagine that one might train someone to always offer their seat on the bus to someone in more need of a seat by punishing them if they did not offer their seat. We can categorise this as James Mill's attitude. John Stuart Mill, on the other hand, wants people to offer their seats to those in greater need because that is the right thing to do, and they would, themselves, feel bad if they did not do the right thing.

This prompting conscience could also be the result of inauthentic training, as Mill himself notes. He criticises himself for relying too heavily on his father for his moral responsibilities, and not shouldering them himself (Mill 1981c, 613). However, conscience could evidently also be authentic, so long as, to borrow Mill's metaphor, it speaks with our own voice, and not that of our trainer (ibid.). The difference is between doing something because someone external will reward you, and doing something because one's own feelings lead one inexorably towards it. In the first case, being brought by our powers of analysis to realise that we only do the 'good' thing because we have been trained to do it will sap our motivation to ever do it again, because we do not, ourselves, authentically believe that it is good - we are only authentically attracted to either the reward or to avoid the punishment. Mill's preferred form of motivation, however, relies on us having an authentic belief in the goodness of an action which is not dependent on the pleasure or a reward for doing it, or the pain of punishment for not doing it. This kind of motivation is free from the destructive power of analysis, because analysis will only help us see more clearly why this particular action will help us achieve an end we have already agreed is good (this is particularly useful for Mill, as he is a consequentialist). Thus, analysis actually strengthens the motivation as it is easier for us to see which the right course of action is. 
In sum, then, Mill lost faith not in associationist psychology, but in the premises drawn by both Hartley and his father from the belief that all our ideas come from outside ourselves and are 'associated' in our mind. He believed that ideas and goals to which we are attached merely through being trained to associate them with pleasure are under attack from our powers of analysis. Partly because of this, partly because we will only act upon things which our emotions motivate us to act upon, and partly because Mill attached an independent importance to authenticity, he rejected that aspect of his father's philosophy of persuasion which relied on bringing people to associate certain ideas with pleasure and others with pain. These three reasons are not, however, the only ones because of which Mill rejected his father's persuasive methods. I will now, therefore, turn to an examination of the other three.

Fourth on my initial list is the problem Mill identified with argumentative debate - namely, that it made people cling more stubbornly to their original opinions. Mill seems to have generated this idea after being drawn to some of the ideas of the Coleridgeans he debated at the London Debating Society (indeed, one can discern a Romantic influence in Mill's concern for authenticity discussed above) (Mill 1981a, 159-63).

The Coleridgeans felt themselves (and were felt by many Benthamites) to be in complete opposition to Benthamism and, in the heat of debate between Mill and the Coleridgean John Sterling (and presumably in the desire for victory) Mill felt that both he and Sterling had gone too far in abusing each other's views; it led to Sterling's resignation from the Society, and, Mill feared, to the ending of their friendship (Mill 1981d, 162; Mill, 1963a, 29). This prompted Mill to write a contrite letter to Sterling, insisting that he was 'resolved hereafter to avoid all occasions for debate, since they cannot now strengthen my sympathies with those who agree with me, \& are sure to weaken them with those who differ' (Mill 1963a, 30). Indeed, Mill seems to have begun to believe that all argumentative debate only made people, through misplaced pride, cling to their existing beliefs (Mill 1963b, 46). This problem was compounded by the fact that argumentative debate made people associate changing their mind with the feeling of defeat, and hence he determined to abandon it (ibid.). Mill felt this problem so strongly that he resigned his membership of the London Debating Society which he had been instrumental in founding only a few years before. Such a rejection of head-on debate is a complete rejection of Mill's father's persuasive method, which was all about argu- 
mentative debate with rational argument, and forcing people to see the truth, and thus the correct nature, of ones own opinions.

In addition, Mill took this problem with debate even further, and also eschewed the idea of 'sectarianism', which he felt promoted the spirit of debate, even when argumentative debate was not happening. Before his 'crisis' Mill had been happy to identify himself as a Utilitarian and as a 'philosophical radical'. After his crisis, he determined to no longer be seen as an 'advocate' either for, or against, any cause (ibid.). This, similarly, is a rejection of his previous method of debate, which was concerned with being 'sectarian' and promulgating a set of beliefs identified with the sect to which one belonged in opposition to the other, erroneous, ideas abounding in society.

Mill's experience at the London Debating Society is also instrumental in the fifth reason I gave above for his rejection of his father's philosophy of persuasion, namely a determination that no one's opinions were wholly correct, or wholly wrong. This also flies in the face of his father's methods of persuasion, which brooked little self-doubt or discussion. During his 'crisis', however, Mill determined that the greatest danger to society was of people being too partial in their views, going so far as to declare that 'no powers of mind are any protection against the evils arising from imperfect and partial views' (Mill 1963c, 42).

Apart from the question of women's suffrage, Mill's previous thought had been almost identical to his father's (and Mill's position on women's enfranchisement was the same as Bentham's, so it was hardly too-radical a departure) (Mill 1981a, 133). As a part of this, both Mills, in the 1820s, despised Tories, aristocrats, and all others not in favour of their programme of reform (ibid.). The thought that anyone from one of these opposing camps might have something to contribute, never mind might have a portion of the truth on their side, was anathema (ibid.). Yet this was exactly what Mill was saying; and, moreover, he was admitting that his own ideas were not a hundred percent correct. More even than declaring that one's opponents might have something to say for their point of view, Mill turned away from the very idea of being sectarian, and determined rather that one should be in search of many-sidedness. His father's philosophy of persuasion, therefore, which relied on the arguments put forward being true, and also, on opponent's arguments being wrong, did not fit in with this new realisation that there could be some truth on both sides of an argument, and had to be rejected.

I come now to my sixth and final point, that critical debate was one of the symptoms of the deeper problems of Mill's time, 
problems that could partly be cured by a movement away from this kind of antagonistic thinking. This is also probably the most complicated point to make, encompassing as it does a number of changes not only to Mill's ideas about persuasion, but also to his wider political theory.

One aspect of Mill's movement away from his father was his repudiation of his father's philosophy of history, a shift which was triggered by Thomas Macaulay's attack on James Mill's historicity in his Essay on Government, and by James Mill's response to this, which Mill found unsatisfying (Mill 1981a, 165-7). From this dissatisfaction, and through his reading of Saint-Simon and the Saint-Simonians, Mill began to think that institutions should be judged in three different ways: which institutions would be theoretically guaranteed to generate the greatest happiness of the greatest number; what was best the time could have produced; and which institutions best aided the progress of their age. Thus, for instance, representative democracy with universal suffrage was right for now, without doubt. It was also, without doubt, a better kind of society than a nondemocratic one, but that was not to say that feudalism 'may ... have not only been highly useful but absolutely indispensable; the only means by which the human mind could have been brought forward to an ulterior stage of improvement' and thus, the right and most progressive kind of society for the Middle Ages (and argument which echoes Saint-Simon's writings on monasteries, which are not suitable for modern times, but were highly useful in the Middle Ages, furthering all sorts of social progress such as draining land, founding hospitals, making the laity literate, and deciphering ancient manuscripts) (Mill 1981a, 167; Mill, 1986257 and 305-6; Mill 1963c, 41; Saint-Simon $1952,15)$. This is tantamount to a direct condemnation of his father's own attitude to history, and reasoning in the social sciences, and marks an important departure from his own earlier political thought, as well as confirming to Mill that one sideand particularly his father's side - of the argument was not guaranteed to be completely correct and that, therefore, his philosophy of persuasion was incorrect.

As well as adopting the Saint-Simonian attitude to judging historical social institutions, Mill also adopted from them a new vision of history as moving between 'organic periods' of social stability, and 'periods of transition' or 'critical' ages, where social stability, and social institutions, were being broken down, ideas he drew from Saint-Simon, Comte (who was a SaintSimonian at this time), and from Mill's close friend Gustave d'Eichthal (Mill, 1981a 171-3; Mill, 1963c 42; Mill 1986, 227- 
$35,238-46, \quad 252-8, \quad 278-83,289-95, \quad 304-7$ and 312-17; d'Eichthal, 11; Saint-Simon 1976, 187). This idea is also key to his determination of what was wrong with his father's philosophy of persuasion.

In order to help clarify this idea of organic and critical periods, Mill presents as examples of organic epochs the periods in Greek and Roman history when the pantheon of gods was really believed in, and similarly the mediaeval period when people really believed in justification of the spiritual and temporal power of the Catholic Church (Mill 1981a, 171). For critical periods he offers the Greece of the Greek philosophers and the Reformation which, Mill argues, ushered in a critical period which 'has lasted ever since, still lasts, and cannot altogether cease until a new organic periods has been inaugurated by the triumph of a yet more advanced creed' (ibid.).

This change in Mill's philosophy of history had a direct bearing on his attitude to his father's philosophy of persuasion. Firstly, it confirmed Mill's belief that there were many sides to an argument, and that an opinion, though it may be true now, is not necessarily eternally true: although James Mill was right to think that representative government was a better form of government than any that had gone before, and was also the best form of government for current society, it was still possible that there might be an even better way of governing, and that James Mill's form of representative government was not necessarily the last word in human progress. Secondly, it gave Mill a tool for characterising his own period of history, understanding what was happening during it, and determining his own role within it.

Mill realised that he was living in a 'critical' age, where all opinions were up for grabs and there was no over-arching ideology in which everyone believed and which could provide social harmony. He further determined that argumentative debate, in which neither side believed in the same (or indeed, any) higher authority to which they could appeal for an adjudication or justification was not only a symptom of a critical age, but was prolonging it (Mill 1963b, 46). He also insisted that he had 'a great dislike of controversy, and am persuaded that discussion, as discussion, seldom did any good' (Mill, 1963b 45). Mill concluded that he was 'unwilling to strengthen this spirit by maintaining any opinions in the spirit of argumentation and debate' (ibid.).

Thus, Mill took from the Saint-Simonians, and his own discomfort with the dichotomy between his father and Macaulay on the role of history in social science, a belief that history is best understood as a progressive journey which moves between 
organic and critical ages. As history had moved from the organic period of the Church-dominated Middle Ages through the critical period of the Reformation the end of which Mill felt himself to be living in, the goal was to bring society into a new organic period which would combine maximum progressiveness with social harmony (Mill 1981a, 173). 'The spirit of argument and debate' and 'controversy' were only prolonging this 'critical' period. Mill's philosophy of persuasion in the early 1820 s, which he had inherited from his father, was in just such a spirit. I contend, therefore, that Mill thus determined to abandon the philosophy of persuasion he had adopted in the early 1820s, and search for a method more suited to, and to creating, a new organic age. Mill had three reasons for this. Firstly, because, given his new understanding of history, an organic age was inevitable (ibid.). Secondly, because, given that inevitability, he wished to make it as desirable an age as possible-indeed, he seems to have believed that we might create the final organic age, after which 'religious, ethical and political' creeds would no longer 'require to be periodically thrown off and replaced by others' (ibid.). Thirdly, because although he desired the freedom of thought and individual action so characteristic of a critical age, Mill also desired the "firm convictions as to right and wrong, useful and pernicious, deeply engrave on the feelings ... and well grounded in reason and the true exigencies of life' which characterise an organic age (ibid.).

For these six reasons, then, Mill rejected his father's methods of persuasion: because they would only lead to artificial opinions and beliefs; because these opinions would be susceptible to being destroyed by our powers of analysis; because, therefore, no one would act on them; because debate only made people cling more strongly to their erroneous beliefs; because it made no allowance for his own opinions to be wrong; and because it was adding to the already existing problems of a critical age. What was needed was a return to an 'organic' age, with some sort of harmony and agreement about the basic fundamentals of social institutions and morality (ibid.). This organic age would not be brought about by confrontational argument, but by engaging in some other philosophy of persuasion. It was this that Mill sought to devise during, and shortly after, his mental 'crisis', writing to a friend that he had determined that it would be 'one of the objects of my philosophical and practical labours ... to contribute to the formation of a better spirit' by engaging in public debate and persuasion in another way (Mill, 1963b, 45). Mill explained what this new method would be in a series of letters to d'Eichthal in 1829 and 1830, and having analysed 
what Mill rejected in his old philosophy of persuasion, I will now move onto an examination of his new method.

\section{Mill's new philosophy of persuasion}

Mill's new philosophy of persuasion was concerned with engendering authentic opinions in people which were better than the ones they already had. In order to persuade people of things Mill had realised that argumentative confrontation was not the way forward, and had also realised that authenticity of opinions was both instrumentally and independently important. Thus, Mill hoped to bring people to new opinions by starting with the opinions they already had, and bringing them to change their minds little by little. As he himself put it, the route to everyone having better opinions was not to 'attack their opinions en masse' but rather to 'fix our attention on what is good in those opinions, \& endeavour to lead them on from this \& through this to something better' (Mill 1963b, 45).

Mill's decision not to attack opinions stems most obviously from one of the problems he had with his old philosophy of persuasion - that it led to people clinging more stubbornly to their beliefs through a misplaced sense of pride, and to associate defeat with changing their mind. However, Mill also seems to have become concerned that if one tried to replace someone's opinions en masse, these new opinions could not be authentic. He writes 'you have done little or nothing for a man when you have merely given him an opinion'-what is important is for people to have authentic opinions which influence how they live their lives, and these cannot be replaced in one fell swoop (ibid.). Instead, Mill believed what was needed was to bring people to replace their own opinions little by little, saying that persuasion 'should consist, not in attacking men's wrong opinions, but in giving them that knowledge which will enable them to form right ones that will push off the wrong ones, as the new leaves push off the withered ones of the last year' (Mill, 1963c, 42). This is because only authentic opinions (as noted above) will make men act. As Mill puts it, '[a]n opinion suggests hardly anything to an uninformed mind; it may become a watchword, but can never be a moving \& influencing and living principle within him' and it is only these living principles which will make people act for the better (ibid.).

In implementing his new method, Mill appears to be trying to walk a tightrope between two conflicting desires. Firstly, he wants to present people with the other side of the truth in 
which they believe, yet secondly, he does not want to put their backs up with direct argument, for, as discussed above, this only has the effect of making them cling - out of misplaced pride - to partial, and hence erroneous, beliefs. I contend that, after his 'crisis', Mill sought to solve this problem by incrementally revealing to people as much of the truth he thought they had not seen as he thought they could stomach without becoming defensive - though he did not intend merely to pander to their existing prejudices - and by trying to bring them to see for themselves the inconsistency or error of their existing opinions (what Rosen refers to as a 'Socratic moment') (Rosen, 45). Mill's goal, then, was seriously to challenge people's erroneous and partial beliefs, but in such a way as people would be able to accept the truth of his argument, or that the seeds of that truth would grow in their own minds without feeling that such a change of mind was a humiliating defeat. One of the outcomes of this plan for bringing about social reform is that Mill determined not just to lay out his own opinions, but to reveal them partially, to the extent that he felt his audience would, although challenged by them, also accept them. Mill had to do this because he believed that one had to begin with what people already believed, and get them to change their minds little by little, which was not achievable by attacking their opinions en masse, by presenting them with a whole new way of thinking about the world, or a whole raft of proposed reforms. Rather, Mill was concerned to start with what was true in someone's erroneous opinions, and, by ensuring they had grasped why that was true, slowly bring them to new, better, opinions. It would be self-defeating, therefore, of his persuasive texts to always reveal everything he believed, or every reform he hoped for - rather, he had to persuade people of the next step towards a better, truer, set of beliefs from their current standing point, which might be a long way from Mill's own.

This is not to argue that we should consider Mill's texts as being 'exoteric'-having one message for the uninformed reader, and a deeper, more meaningful and possibly even contradictory message for the intelligent, careful, philosophical reader (Strauss, 36). I do not mean to argue that Mill felt prevented from openly declaring his beliefs because of governmental persecution; or at least, I do not mean to argue that this is the best way of understand all of Mill's texts. For example, although Mill himself admitted he kept his atheism mainly secret for fear that his works would simply not be read if he was thought to be an atheist, and also because of the fear of public ostracism or even legal penalty, and even went so far as to invoke Providence 
and use other religious language in some of his works, and was particularly careful to defend the philosophes from the charge of 'irreligion', his atheism is not 'hidden' in these works, nor to be read 'between the lines' of them (Mill 1981a, 41; Mill 1972a, 491-2; Mill, 1967 26; Mill 1985, 66; Strauss 22-36).

Rather than governmental persecution, what Mill was concerned about was that he would simply not be listened to if he was too combative; and he felt that any form of direct, critical argument was too combative because it split men into camps and made them cling to their partial, erroneous beliefs out of pride. Hence, I contend that Mill determined not to reveal the full extent of his opinions on particular matters all at once, because he knew it would not be listened to. Instead, he allowed himself publicly to affirm so much of it as he thought would be accepted by (though still be a challenge to) contemporary society; once they had seen the truth of part of his ideas, had authentically accepted them, and had adjusted their own to them, then Mill would challenge them a little further with some other aspect of his thought.

It might be objected that what Mill has to say in On Liberty castigating thinking men for hiding their thoughts might preclude him from having a philosophy of persuasion such as I am outlining (Mill 1977, 241-2). But it does not seem impossible that in Liberty Mill is criticising the weight of contemporary stigma on himself as much as on anyone else. Certainly it seems unlikely that Mill considered himself so completely economically and politically independent he could class himself amongst those who can afford to be brave, especially in earlier life.

Given this new understanding of Mill's philosophy of persuasion, discovering what Mill's complete set of ideas were becomes not an entirely straightforward endeavour. Rather, each of his texts is in some way a facet of his whole political thought. The task, then, is to try and piece together from what Mill does reveal in his texts, what this underlying political philosophy was, and especially at what kind of political and social reform Mill was aiming.

Importantly, as I noted at the very beginning of this piece, it is vital to note that a large number of Mill's texts employ this philosophy of persuasion. This means, however, that any texts composed after around 1830 need to be read in the light of Mill's new persuasive philosophy. In particular, I contend, this means that more weight than is often currently ascribed to private texts needs to be given-where Mill is not engaged in an act of persuasion we are more likely to see more of his political thought, whereas his public and persuasive texts are likely only 
to hold as much of the truths he held as he felt was useful to publish at the time. Indeed, Mill goes as far as to say that this is the case when he admits he did not publish something in support of the Northern States in the American Civil War when Britain seemed on the brink of war with them itself as 'there was no chance of getting a hearing' for it - that is, writing to express his support would only have alienated readers and been part of a destructive spirit of controversy, rather than helping to persuade the public to sympathise with the Northern cause (Mill, 1972b, 733).

It must be noted, however, that not all of Mill's private correspondence is non-persuasive, so the distinction between persuasive and non-persuasive is not as simple as that between public and private. Indeed, bearing in mind Mill's recent commitment to seeing both sides of the debate, and not tackling other people's opinions head-on can help, I contend, make sense of some of his private correspondence when we realise that it, too, is often persuasive.

A good example of this, and also a good case-study for my whole argument, is Mill's pronouncements on women's rights, particularly a comparison of what he says in On Marriage, in his correspondence with Auguste Comte on the question, and his deliberate silence about divorce in The Subjection of Women. The differences in his revealed opinions in these texts have even led to Mill being accused of dissembling (Raeder, 46-72). ${ }^{4}$ However, I think a better understanding of his philosophy of persuasion makes what is occurring much clearer.

In Marriage (a private text meant only for the eyes of Harriet Taylor), Mill clearly declares that ' $[\mathrm{t}]$ here is no natural inequality between the sexes', dismisses institutionalised sexism based on biological differences, and declares forthrightly in favour of divorce (Mill 1984a, 41-2 and 45). In his correspondence with Comte, Mill seems willing to accept that it is possible that women are naturally incapable of as much intellectual achievement as men, though he emphasises the need for precaution because women currently receive a very different education to men, and says the question of divorce is 'indécise' (Mill 1963d, 564). In Subjection, Mill dismisses the idea that female inequality can be justified by biological differences, and refuses to be drawn on the question of divorce (Mill 1984b, 285). This

\footnotetext{
${ }^{4}$ Similarly, Hamburger accuses Mill's use of rhetoric of being 'intended to disguise, conceal, equivocate, and mislead' (Hamburger 1999, 203). I think, however, that this is to misinterpret Mill's project.
} 
apparent inconsistency can, however, I feel, be solved by a proper understanding of Mill's philosophy of persuasion.

Given the context of Marriage-Mill was writing privately to someone of at-least equally feminist views and was, moreover, potentially engaged in trying to persuade her to leave her husband - it seems plausible to think Mill was at his most open in it (Robson, 1x). On the other hand, Mill was in an entirely different position when he published Subjection, with which he was intending to bring about a particular political act - the granting of the suffrage to women. Given this particular political goal — and given also the extreme radicalism of support for divorce at the time-it seems Mill would have very good reasons for leaving his opinions on divorce out of the question (and perhaps also, in his apparent reassurance to men that women will still choose to be housewives and mothers if they are given equal political rights, for refusing to reject the idea that woman's 'nature' is the same as men's, though he does tackle the question of biology being a good foundation for denying women any political rights at all) (Mill 1984a, 285 and 2978). Thus, if I am right about his philosophy of persuasion, we can see Mill in Subjection tackling contemporary ideas about women still in a radical fashion, but often from premises his audience have already accepted (about the nature of marriage as a loving partnership, for instance), but holding back on the full extent of his radicalism, as this would merely alienate his audience (Urbinati, 640). Rather than being dishonest in Subjection, therefore, Mill is merely leaving out of the debate ideas which will not help him bring his audience to new, authentic ideas which will prompt them to a desired action (pressurising the government to grant women equal rights).

Something similar is, I think, occurring in Mill's correspondence with Comte, in which Mill expressed indecision on opinions that, at home, he evidently expressed more firmly (Taylor, 337). The correspondence, although ostensibly private was written, at least on Mill's part, it would seem, with an eye to posterity and possible publication (Mill 1963e, 540; Rosen, 98). This would be one good reason for Mill not revealing all his opinions, for much the same reasons as it was when he was publishing Subjection (though in this case, Mill's goal would not be the emancipation of women, but the wider acceptance of positivism, and striking a blow against 'metaphysical' philosophy, another cause very close to his heart).

Moreover, even without having an eye on potential future publication, there are other good reasons for Mill not to enter into an antagonistic debate with Comte. It was very important 
for Comte - and I think also for Mill - that they agreed (Rosen, 12 and 101-109). Initially, this may have been mainly due to Mill's feelings of respect, admiration and deference for Comte. Moreover, the positivist project was an important one for Mill, both, as Rosen points out, because it would help him in his battle against 'metaphysical' philosophy, and also, I think, because positivism was - in name and nature - the opposite of the 'negative' philosophy of the Enlightenment which, for Mill, epitomised the 'critical' age, and which was, as outlined above, preventing society from entering into a new, better, organic age (ibid.). In addition, Mill and Comte were engaged in what was, for Mill, a vital discussion about the nature of sociology and logic; the possibility of Mill's projected 'ethology' and the intellectual position of political economy: the question of Comte's position on women may have seemed peripheral when so much else was at stake, and it would certainly not be worth jeopardising the whole positivist project by antagonising Comte (who was, after all, rather easy to antagonise) (ibid.). Mill, then, had several imperative reasons for trying to persuade Comte to authentically change his opinions to become closer to Mill's, without antagonising him-a perfect situation for the deployment of Mill's new philosophy of persuasion. If we see Mill deploying this philosophy, then what we find in the correspondence is not Mill changing his mind on feminist issues, or being inconsistent, but an attempt on Mill's part to persuade Comte without antagonising him, which would be self-defeating for a number of reasons.

\section{Conclusion: Mill's philosophy of persuasion}

In this article I have endeavoured to show that any attempt to understand Mill's work after 1826/7, and thus the period in which all his important works were written, needs to take cognisance of the fact that most of the texts we may want to study are persuasive texts, and that Mill had a very specific, and individual philosophy of persuasion. Importantly, this philosophy of persuasion was concerned to bring people to a better understanding of their own point of view, and then to incrementally change that point of view until they not only held better opinions, but held those opinions authentically. In order to bring about this incremental, authentic, change, Mill abandoned his earlier practice of argumentative debate, in which other people's opinions were picked apart and proved wrong or irrational (or 
both), and one attempted to replace these erroneous ideas with one's own logical arguments, which people were forced to accept simply because they could not deny the truth of them. Rather, he sought to reveal only so much of his own beliefs as would be usefully challenging to public opinion- 'usefully' here meaning either having a chance of being accepted after some thought, or of at least bringing people to slightly better opinions without appearing so opposing and argumentative as to make people cling to their erroneous beliefs through misplaced pride.

As well as explaining Mill's previous theory of persuasion, what he felt was wrong with it after his 'crisis', and what new method he adopted after 1826/7, I have also endeavoured to give an example of how employing this understanding of what Mill is doing can change our reading of his work in an examination of some of his apparent inconsistencies on feminism. My conclusion, however, has a wider implication than this one example, for I hope that I have shown that the realisation that this is how Mill chose to argue, coupled with the fact that almost all of his texts are persuasive, means that we need to bear in mind who Mill considered to be his audience, what change he might have been trying to bring about, and the context within which he was arguing (which reveals how radical he could afford to be) whenever we read any of Mill's works. As I said at the very start of this article, the immediate content of Mill's writing after $1826 / 7$ does not reveal everything about his political theory, and cannot be all we consider when assessing his political, social and economic thought.

\section{References}

Canovan, M. (1987). The Eloquence of John Stuart Mill. History of Political Thought, 8/3, 505-515.

d'Eichthal, G. (1831). Rapports adressés aux Pères Suprèmes sur la Situation et les Traveux de la Famille. Paris: $\mathrm{Au} \mathrm{Bu-}$ reau du Globe et de L'Organisateur.

Ekelund, R.B. and Tollison, R.D. (1976). The New Political Economy of J.S. Mill: The Means to Social Justice. The $\mathrm{Ca}$ nadian Journal of Economics, 9/2, 213-231.

Feuer, L. (1946). J.S. Mill and Marxian Socialism. Journal of the History of Ideas 10/2, 297-304.

Flew, A (1975). J.S. Mill: Socialist or Libertarian? In: Michael Ivans (ed.), Prophets of Freedom and Enterprise (pp. 21-6), London: Kogan Page for Aims of Industry. 
Fredman, L.E. and Gordon, B.L.J. (1963). John Stuart Mill and Socialism. Mill Newsletter 3/1, 3-7.

Hainds, J.R. (1946). John Stuart Mill and the Saint-Simonians. Journal of the History of Ideas 7/1 103-12.

Hamburger, J. (1963). James Mill and the Art of Revolution. New Haven and London: Yale University Press.

Hamburger, J. (1999). John Stuart Mill on Liberty and Control. Princeton: Princeton University Press.

Hartley, D. (1749). Observations on Man. London: S. Richardson.

Hugeulet, T. (1966). Introduction, David Hartley, Observations on Man. Gainesville: Scholars' Facsimiles and Reprints.

Hollander, S. (1985). The Economics of John Stuart Mill Volume 2: Political Economy. Oxford: Blackwell.

Kurer, O. (1992). Mill and Utopian Socialism. The Economic Record, 68/3, 222-232.

Losman, D. (1971). J.S. Mill on Alternative Economic Systems. American Journal of Economics and Sociology 30/1, 84-104.

Marx, K. and Engels, F. (1975). The Communist Manifesto (Karl Marx and Frederick Engels: Collected Works, 6). New York: International Publishers.

Mill, J. (1825). The Article Education, Reprinted from the Supplement to the Encyclopaedia Britannica. London: J. Innes.

Mill, J. (1826). Elements of Political Economy London: Baldwin, Craddock and Joy.

Mill, J. (1869). Analysis of the Phenomena of the Human Mind. London: Longmans, Green, Reader, and Dyer.

Mill, J.S. (1963a). Letter 25, to John Sterling, 15 April 1829, ( $C W \mathrm{XII})$. Toronto: University of Toronto Press.

Mill, J.S. (1963b). Letter 29, to Gustave d'Eichthal, 9 February 1830 ( $C W$ XII). Toronto: University of Toronto Press.

Mill, J.S. (1963c). Letter 28, to Gustave d'Eichthal, 7 November 1829 ( $C W$ XII). Toronto: University of Toronto Press.

Mill, J.S. (1963d). Letter 371, to Auguste Comte, 10 September 1842 (CW XIII). Toronto: University of Toronto Press. (trans. Oscar Haac, The Correspondence of John Stuart Mill and Auguste Comte. New Brunswick: Transaction Publishers, 1995, 100-102.)

Mill, J.S. (1963e). Letter 367, to Auguste Comte, 20 August 1842 ( $C W$ XIII). Toronto: University of Toronto Press. (trans. Oscar Haac, The Correspondence of John Stuart Mill and Auguste Comte. New Brunswick: Transaction Publishers, 1995, 92-3.)

Mill, J.S. (1965a). Principles of Political Economy I (CW II). Toronto: University of Toronto Press. 
Mill, J.S. (1965b). Principles of Political Economy II (CW III). Toronto: University of Toronto Press.

Mill, J.S. (1967). The Quarterly Review on Political Economy ( $C W$ IV). Toronto: University of Toronto Press.

Mill, J.S. (1972a). Letter 336, to Comte, 18 December 1841 ( $C W$ XIII). Toronto: University of Toronto Press. (trans. Haac, Correspondence of Mill and Comte, 41-3).

Mill, J.S. (1972b). Letter 528, to John Elliot Cairnes, 20 January 1862 ( $C W \mathrm{XV}$ ). Toronto: University of Toronto Press.

Mill, J.S. (1972c). Letter 348, to Comte, 22 March 1842 (CW XIII). Toronto: University of Toronto Press. (trans. Haac, Correspondence of Mill and Comte, 60).

Mill, J.S. (1972d). Letter 401, to Comte, 30 August 1843 (CW XIII) (trans. Haac, Correspondence of Mill and Comte, 1834).

Mill, J.S. (1977). On Liberty (CW XVIII). Toronto: University of Toronto Press.

Mill, J.S. (1981a). Autobiography (CW I). Toronto: Toronto University Press.

Mill, J.S. (1981b). A Few Observations on Mr Mill (CW I). Toronto: Toronto University Press.

Mill, J.S. (1981c). Autobiography, Early Draft: Rejected Leaves, ( $C W \mathrm{I})$. Toronto: University of Toronto Press.

Mill, J.S. (1981d). Early Draft of the Autobiography, (CW I). Toronto: University of Toronto Press.

Mill, J.S. (1981e). Writings of Junius Redivivus [1], (CW I). Toronto: University of Toronto Press.

Mill, J.S. (1984a). On Marriage (CW XXI). Toronto: University of Toronto Press.

Mill, J.S. (1984b). The Subjection of Women ( $C W$ XXI). Toronto: University of Toronto Press.

Mill, J.S. (1985). Scott's Life of Napoleon (CW XX). Toronto: University of Toronto Press.

Mill, J.S. (1986), Newspaper Writings (CW XXII). Toronto: University of Toronto Press.

Mill, J.S. (1989), Preface, James Mill's Analysis of the Phenomena of the Human Mind, (CW XXXI). Toronto: Toronto University Press.

Raeder, L. (2002). John Stuart Mill and the Religion of Humanity. Columbia: University of Missouri Press.

Riley, J. (1996). J.S. Mill's Liberal Utilitarian Assessment of Capitalism versus Socialism. Utilitas 8/1 pp. 39-71.

Robson, J. M (1984). Textual Introduction to Collected Works of John Stuart Mill XXI. Toronto: University of Toronto Press. 
Rosen, F. (2013). Mill: Founders of Modern Political and Social Thought. Oxford: Oxford University Press.

Saint-Simon, H. (1952). Introduction to the Scientific Studies of the Nineteenth Century, Selected Writings, trans. F.M.H. Markham. Oxford: Basil Blackwell.

Saint-Simon, H. (1976). The Catechism of the Industrialists, trans. Ghita Ionescu. Oxford: Oxford University Press.

Schapiro, J. S. (1943). John Stuart Mill, Pioneer of Democratic Liberalism in England. Journal of the History of Ideas 4/2, 127-60.

Schofield, P. (2006). Utility and Democracy: The Political Thought of Jeremy Bentham. Oxford: Oxford University Press.

Schwartz, P. (1966). John Stuart Mill and Laissez Faire: London Water. Economica, New Series, 33/129 71-83.

Strauss, L. (1952). Persecution and the Art of Writing. Westport: Greenwood Press.

Taylor, H. (1998). Letter to John Stuart Mill, probably 1844, The Complete Works of Harriet Taylor Mill. Bloomington: Indiana University Press.

Thomas, W. (1985). Mill. Oxford: Oxford University Press.

Urbinati, N. (1991). John Stuart Mill on Androgyny and Ideal Marriage. Political Theory 19/4, 626-648.

Winch, D. (2009). Wealth and Life: Essays on the Intellectual History of Political Economy in Britain, 1848-1914. Cambridge: Cambridge University Press.

The Times, 31 August 1832. 